\title{
ЛИКИ РЕНЕССАНСА: ДИСПОЗИТИВНЫЕ СТРАТЕГИИ, ПСИХОТЕХНИКИ И СЕМИОЗИС. Часть 1
}

\begin{abstract}
Аннотация: В статье изложена история символических полей эпохи Ренессанса, которая выстраивается на основе диспозитивной концептуализации М. Фуко и оригинальной теории эпистемогенеза, разработанной автором. Выявляются диспозитивные стратегии, психотехники и семиотические прои,ессы, связывающие ренессансных твориов и «обывателей». Показана система диспозитивных трансформаций, обусловленных изменением внутреннего содержания символа «обновление» в период X-XVI вв. Действуя как эпистемическая вещь, наделенная семантически сложным культурным имплантом, символ «обновление» вызывает к жизни гетерогенную серию диспозитивов, которые производят психокультурные феномены, известные под именами «Возрождение», «Реформация», «гуманизм» и «соииальная утопия». На основе двучастности символа «гепассі» обсуждаются дифференциичии в духовных практиках позднего средневековья, которые ведут красщеплению «обновленческого» диспозитива в "ренессансный» $u$ «реформационный». Показано, что исторические процессы при этом протекают скорее через диспозитивный генез, а не культурный разрыв. Череда диспозитивных трансформаций выстраивает психокультурное движение ренессансной эпохи и несет в себе объяснение того, почему события развивались так, а не иначе.
\end{abstract}

Ключевые слова: психология, психотехники, христианство, диспозитив, эпистемическая вещь, Ренессанс, Ребормачия, гуманизм, социальная утопия.

\section{Введение: диспозитивы Фуко}

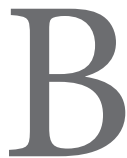

этой работе нам предстоит рассказать особую историю эпохи Ренессанса - историю символических полей, в которую погружены ее творцы и «обыватели»; историю, которая выстраивается через диспозитивные стратегии, психотехники и семиозис.

Протоидея, вдохновившая Ренессанс и Реформацию, связана с модернизирующей силой образа «обновления». В более широком плане может идти речь о влиянии идеи и ее развертывания на культурные процессы, социальную структуру и материальную жизнь. Такое воздействие оказывается на весьма гетерогенный объект, который аналитика Фуко пыталась ухватить под именем «диспозитив». B «Воле к знанию» французское слово dispositif наделяется новым семантическим содержанием ${ }^{1}$. Диспозитив - это

\footnotetext{
1 В использовании термина «диспозитив» мы в значительной степени опираемся на семантику, которую внес Фуко во французское слово dispositif (до этого оно означало, например, «устройство», «механизм», «расположение», «порядок»). В дискуссии с лаканистами Фуко, говоря о смысле и методологической функции термина «диспозитив», выделяет ряд содержа-
}

тельных позиций в его значении. Во-первых, диспозитив - это сеть, которая может быть установлена между элементами некоторого радикально гетерогенного ансамбля. Он может включать в себя, например, «дискурсы, институции, архитектурные планировки, регламентирующие решения, законы, административные меры, научные высказывания, но также и моральные ...». Во-вторых, Фуко выделяет в понятии диспозитива природу связи, «которая может существовать между этими гетерогенными элементами». Он говорит, что между дискурсивными и недискурсивными элементами диспозитива «существуют своего рода игры, перемены позиций, изменения функций ...». Так, некий дискурс может быть программой институции, оправдывать и прикрывать практику, функционировать как переосмысление этой практики, еtc. В-третьих, диспозитив есть «образование, важнейшей функцией которого в данный исторический момент оказалось: ответить на некоторую неотложенность». В разрабатываемой нами теории роль такой «неотложенности» играет эпистемическая вещь. Говоря об эпистеме, Фуко отмечает, что «это специфически дискурсивный диспозитив тогда как, вообще говоря, диспозитив может быть как дискурсивным, так и не-дискурсивным, поскольку его элементы куда более гетерогенны»*. В нашем случае мы имеем дело с не-дискурсивным диспозитивом, включающим дискурсы в качестве элемента в свою гетерогенную сеть.

* Foucault M. Dits et écrits. 1954-1988. En 4 volumes. T. III. P.: Callimard, 1994. P. 299. 


\section{Философия и психология}

фиктивное единство ${ }^{2}$ и особая культурная группировка. Он вовлекает в себя общественные институты, правила морали, аппараты власти, модели поведения, инструменты познания, торговые сети, социальные группы, типы рациональности, гендер, право, этнос, еtс., т.е. все то, что может быть мобилизовано на дело служения объединяющему интересу. Фуко говорит, что в понятии диспозитив он стремился выделить природу связи, «которая может существовать между этими гетерогенными <разнородными> элементами». В то же время диспозитив - это «образование, важнейшей функцией которого в данный исторический момент оказалось: ответить на некоторую неотложность». Таким образом, диспозитив есть сеть объектов и отношений, обеспечивающая культурное действие; он форма институализации культурных практик, основа их социальной легитимности и генератор эпистемической активности.

Та неотложность, на которую отвечает диспозитив, в своем человеческом значении проступает через вопрос, который кто-то задал, через проблему, которую некто сформулировал, т.е. через творчество мысли живого cogito, объективирующего в них недостаточность своих отношений с миром. Став такого рода объектом, и вопрос, и проблема обретают статус вещи эпистемической вещи ${ }^{3}$, которая при удачном стечении обстоятельств пройдет путь от символа, идеи через концептуализацию к теории или факту, видящему себя как решение. И здесь не важно, к какому пониманию идет дело - научному, теистическому, культурному или социальному.

\section{Протоидея}

Протоидея, вдохновившая Ренессанс, связана с модернизирующей силой образа «обновления». Культурно-филологический анализ, проведенный Конрадом Бурдахом, высвечивает массив репликаций эпистемической вещи, функционирующей в синонимичной этому образу системе имен. Его исследования показывают как в религиозных взглядах античности «возникают параллельно и заменяя друг друга» понятия reformatio, renasci, regeneratio, renovatio ${ }^{4}$, которые определяют начало новой

Цит. по: Табачникова С.В. Комментарий // Фуко М. Воля к истине: по ту сторону знания, власти и сексуальности. Работы разных лет. М.: Касталь, 1996. С. 367-369.

2 Фуко М. Воля к знанию. История сексуальности. Том первый // Фуко М. Воля к истине: по ту сторону знания, власти и сексуальности. Работы разных лет / пер. с франц. С.В. Табачниковой. М.: Касталь, 1996. С. 262.

3 Карпов А.О. Эпистемическая вещь и ее артефакты // Психология и психотехника. 2012. № 8 (47). С. 7-28.

4 Re-fōrmo (лат.) - преобразовывать, улучшать, восстанавливать; reformari in primos annos - быть омоложенным. эры, складываются в образ грядущего обновления и преображения в идеальную форму. Как этот образ наследует Новый завет и репрезентирует его в том же терминологическом ряду ${ }^{5}$. Как в соединении «ренессансных» и «реформационных» символов этот образ циркулирует в средневековье ${ }^{6}$, формируя религиозное происхождение и религиозное ядро того, что мы будем называть диспозитивом Обновления и позднее расщепляющих его диспозитивов Реформации и Ренессанса.

Пунктир литературных артефактов, ассимилированных диспозитивом Обновления, его восточно-грекоримская ретроспектива высвечиваются в египетском сказании о Фениксе, в орфических мистериях, в эпохе Августа, восстанавливающей золотой императорский век, и его литературной апологетике - в «Энеиде» и IV эклоге «Буколиков» Вергилия, в «Песни веков» Горация и «Метаморфозах» Овидия, в стихах Марциала, писанных в доминицианово правление, и у Лактанция, поэта диоклетиановых времен ${ }^{7}$. Последний успел понянчить Криспа, сына императора Константина, тем самым расположившись во времени на пороге темных веков. Через сто лет после Константина один из отцов церкви, Блаженный Августин в своих антипелагианских сочинениях напишет: «... одни так, другие по-другому и все по-разному, различными и бесчисленными способами призываются, чтобы быть преображенными» ${ }^{8}$. Те же вербальные единицы циркулируют все средневековье в эсхатологических надеждах, в хилиастических толкованиях грядущего, в песнях францисканских кругов, в алхимических рецептах, в философии, ищущей бескорыстия ${ }^{9}$, и, наконец, в лирике Петрарки и Divina commedia ${ }^{10}$ Данте.

Re-nāscor (лат.) — рождаться опять, возрождаться, воскресать, возобновляться.

Re-genero (лат.) - вновь производить, возрождать, воспроизводить

Re-novo (лат.) - обновлять, восстанавливать, воскрешать, омолаживать.

Дворецкий И.Х. Латинско-русский словарь. М.: Русский язык, 1976. С. 862, 869, 863.

5 Бурдах К. Реформация. Ренессанс. Гуманизм / пер. с нем. М.И. Левиной. М.: Российская политическая энциклопедия (РОССПЭН), 2004. С. 63, 40, 39.

6 Там же. С. 34.

7 Там же. С. $61,71,66,84$.

8 Блаженный Августин. Об упреке и благодати // Блаженный Августин. Антипелагианские сочинения позднего периода / пер. с лат. Д.В. Смирнова. М.: АС-ТРАСТ, 2008. С. 223.

9 Неретина С.С. Возможности понимания // Антология средневековой мысли (Теология и философия европейского Средневековья): в 2 т. Т. 1 / под ред. С.С. Неретиной. СПб: Изд-во Российского христианского гуманитарного института, 2001. С. 11.

10 Божественная комедия (лат.). 


\section{Психология и психотехника 8(59) • 2013}

\section{Схема диспозитивного генеза эпохи Ренессанса}

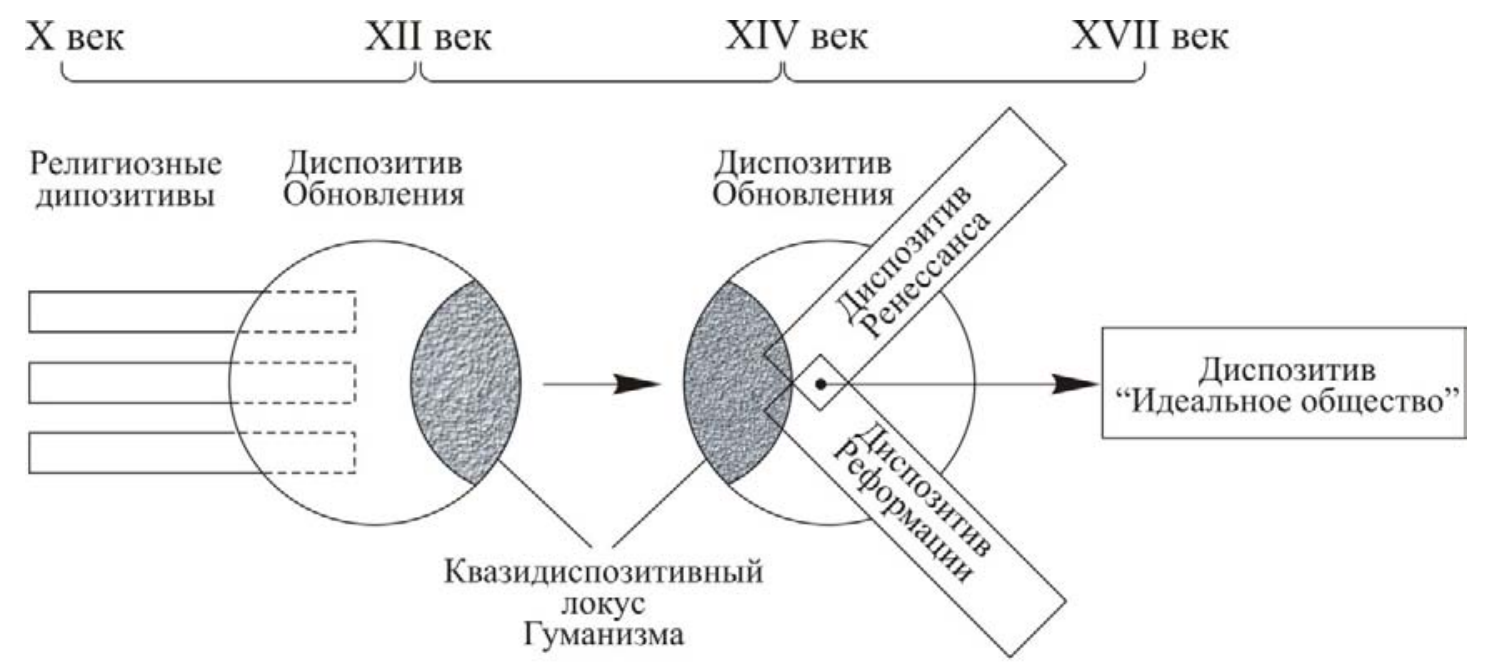

$\longmapsto$ этап ЗАМЕЩЕНИЯ

этап РАСЩЕПЛЕНИЯ

этап ИНКОРПОРАЦИИ,

$\longmapsto$ этап ВЫДЕЛЕНИЯ

Таким образом, эпистемическая вещь, которая может быть обозначена понятием «обновление», имеет в культурной истории богатую эпистемическую коллекцию. За каждым фактом ее ментальной интенсификации стоят диспозитивы, концентрирующие обращенные на нее культурные практики, мобилизующие политическую волю, человеческие коллективы и социальные институты, формирующие мир эмоций, модели поведения и правила вдохновляющей ее этики.

Универсальность образа, стоящего за символом «обновления», способна вызвать к жизни гетерогенную серию диспозитивных структур, каждая из которых видит в этом образе свою личину; причем вызвать в одной временно́й синхронии. Тогда образ этот переживает весьма бурный семиотический процесс. Направленный на него «разношерстный» каскад означиваний возвращает в диспозитивы символически объединенную под его эгидой массу «первичных» содержаний — продукт внутренней коллективной рефлексии образа. Диспозитив интерпретирует ситуационно обогащенный образ, который возвратило его коллективное сознание, канонизирует понимание и «сбрасывает» в то, что обычно называют обществом, организованное по формуле «символ - ситуация - смысл» содержание.

Социальный реципиент получает, таким образом, от окружающих его диспозитивов массив интерпрети- рованного материала, на который наложены канонизированные понимания. Этот материал собирается под знаком одного универсального образа, а, следовательно, набухает, взаимообогащается и воплощается в некоем сверх-плане, сверх-проекте, в некоем трансцендировании культурного понимания и содержания.

Уникальность ренессансного периода заключается в наличии единого духовного процесса, который, развиваясь, стимулирует каскад диспозитивных трансформаций, управляемых символической динамикой образа «обновления». Весь ход диспозитивной истории, о которой нам предстоит рассказать, схематично изображен на рис. 1.

В схеме ренессансного генеза семейство диспозитивов замещается новым диспозитивом, который устанавливается как бы над ними и скрывает их в своей тени; в свою очередь бывший целостным диспозитив расщепляется на диспозитивный пучок, сохраняющий общее ядро; в то же время он подвергается инкорпорации - локальной замене части своей структуры и из него выделяется отдельное диспозитивное тело. В западноевропейской хронике $\mathrm{X}$-XVI вв. диспозитивы эти обуславливают весьма синкретичную систему культурных практик, которые стоят за историческими ярлыками «возрождения», «реформации», «гуманизма» и «социальной утопии». В их жизненном цикле таятся смысл и объяснения того, почему события развивались так, а не иначе. 


\section{Философия и психология}

\section{Религиозные предиественники}

Тысячный год, по словам Ле Гоффа, задает культурный фон на заре Возрождения ${ }^{11}$. На рубеже десятых веков нас будут интересовать диспозитивы, оснащенные сильным религиозным началом, которое регулирует и синхронизирует их деятельность под углом зрения христиански правильных форм жизни. В их мощном звучании рождается «силовое поле» новой культуры, в котором живет предчувствие ярких феноменов будущего ${ }^{12}$. Эта диспозитивная группа дает весомый, если не решающий, импульс процессу формирования к XII западноевропейскому веку макродиспозитива «Обновление», замещающего своим образом и своей истиной сферу их притязаний. Замещающего, конечно, в своем пространстве репрезентацией, которое покрывает плотным культурным слоем их уходящее бытие. Диспозитив становящегося обновления тотально захватывает и религиозное, и светское, и приватное, диктуя миру его новую европейскую судьбу.

Выбирая точкой отсчета Х век, мы имеем ввиду культурную цезуру в жизни европейского средневековья, обладающую, конечно, как и всякий «знак препинания» исторического развития, весьма условным культурным статусом. Репутацию Х веку - «мрачному веку свинца и стали» ${ }^{13}-$ весьма подпортили вторжения мадьяр и норманнов ${ }^{14}$. В этот век «культурного безмолвия» ${ }^{15}$, кажется, иссяк духовный импульс Каролингского возрождения, идущий от правления Carolus Magnus - первого «короля» латинской выделки ${ }^{16}$.

11 Ле Гофф Ж. Другое Средневековье: время, труд и культура Запада / Пер. с франц. С.В. Чистяковой и Н.В. Шевченко. Екатеринбург: Изд-во Уральского университета, 2002. С. 63.

12 Бахмутский В.Я. На рубеже двух веков // Спор о древних и новых. М.: Искусство, 1985. С. 7.

13 Гонсалес Х.Л. История христианства: в 2 т. Т. 1. От основания Церкви до эпохи Реформации / пер. с англ. Б.А. Скороходова. СПб: Издание религиозной организации «Христианское общество «Библия для всех»», 2005. С. 252.

14 В начале $\mathrm{X}$ века норманны захватили земли в Северной Франции и значительную часть Ирландии, в конце $\mathrm{X}$ века они начинают подчинять Англию. После битвы при Прессбурге (4 июля 907 г.) венгры заняли восток сегодняшней Австрии и всю Великую Моравию. Так погибло первое славянское государство - Великая Моравская держава (822-907). Опустошительные набеги мадьяр на Германию, Францию, Испанию, Италию закончились только в 955 г. после поражения в битве на реке Лех (10 августа), которое нанесли им немецкие войска во главе с королем Оттоном I. Эту битву считают «рождением немецкой нации».

15 История Средних веков: в 2 т. Т. 1 / под ред. С.П. Карпова. М.: Изд-во Московского университета; Наука, 2005. С. 589.

16 Карл Великий - Carolus Magnus (лат.), фракский король с 768 г., император в период 800-814 гг. Слово «король»-
Однако этот мрачный век отличился работой по крайней мере двух мощных религиозных диспозитивов, имеющих ввиду проблему «обновления».

То, что историки видят как «движения за обновление» ${ }^{17}$, начиналось с монашеских инициатив X-XI вв., направленных на реформирование монастырей в духе бенедиктианского устава ${ }^{18}$. Сей «ренессансный» порыв с особой силой прозвучал в «далекой» Бургундии, которая сотрясалась от звона копыт мадьярских коней. Монастырь Клюни, основанный в 909 г. герцогом Аквитании Гильомом Благочестивым в его любимом охотничьем угодье, стал в X-XI вв. центром мощного и разветвленного реформаторского движения, стремившегося как к обновлению жизни монастырских обителей, так и к великому возрождению христианского мира $^{19}$. Сетевая структура клюнийского движения ядро его диспозитива - опиралась на сотни монашеских общин, мужских и женских, расположенных по всей Европе ${ }^{20}$. Отклик, который нашло в сердцах европейцев клюнийской движение, его размах казались «чудом, божественным вмешательством, несущим с собой новую зарю», - замечает Хусто Гонсалес ${ }^{21}$.

Бенедиктианская этика аскезы исключала симонию и конкубинат, а в качестве залога христианского благочестия требовала целибат священников. Из этого исходит реформаторское рвение как клюнийского, так и последующих диспозитивов. Конечно, свой интерес здесь находят и борьба за инвеституру ${ }^{22}$ (последняя

производное от имени Карла Великого; это имя было воспринято западными и отчасти южными славянами как титул и использовано для именования своих монархов.

История Средних веков. Т. 1. С. 140.

17 Гонсалес Х.Л. История христианства: в 2 т. Т. 1. От основания Церкви до эпохи Реформации / пер. с англ. Б.А. Скороходова. СПб: Издание религиозной организации «Христианское общество «Библия для всех»», 2005. 256.

18 Устав святости Бенедикта - регламентации религиозной жизни, связанные с именем Бенедикта Нурсийского (480-547), основателя монастыря в Монте Кассино. Устав, созданный в 529 году, предписывал аскетические правила организации монастырской жизни: бедность, целомудрие, послушание, труд, благотворительность.

Мак-Ким Дональд К. Вестминстерский словарь теологических терминов. М.: Республика, 2004. С. 37.

19 Гонсалес Х.Л. История христианства. Т. 1. С. 252, 258, 259.

20 История Средних веков. Т. 1. С. 566.

21 Гонсалес Х.Л. История христианства. Т. 1. С. 258.

22 Симония, от simonia (лат.); средневековая практика торговли церковными полномочиями (должностями, духовным саном) со стороны папства или светской власти; получила название по имени Симона Волхва (Деян 8:18-24).

Мак-Ким Дональд К. Вестминстерский словарь теологических терминов. С. 365 . 


\section{Психология и психотехника 8(59) • 2013}

была объявлена папой Григорием VII «симонией»), и эсхатологически-хилиастические ожидания второго пришествия, связанные с тысячелетним «лагом» евангелической истории, и вытеснение мосарабских богослужений христиан Пиренейского полуострова, инфицированных мусульманской традицией.

Однако, кроме этой страсти к правильным формам жизни, в ряд с ней становится чисто человеческое значение, которое звучит сквозь обличающую инвективу апостола Петра: «... серебро твое да будет в погибель с тобою, потому что mы помыслил дар Божий получить за деньги» (Деян 8:20). Такая этически сфокусированная индивидуальная требовательность, исходя к другому, в тот же самый момент обращается к требующему. Она отражается от диспозитивного символа, взыскующего «обновление», который - в самом сердце, в зрачках соратников, в полемической светотени окружающих коллективов. Говоря так, обретаешь способность говорить духовно с собой, но далеко не всегда знаешь обретенное, знаешь с кем говорить и как говорить, т.е. как выдавливать из себя и в себя речь. И это новое благочестие, которое вызревает, которое возвестят в XII-XIII вв. Иоахим Флорский и Франциск Ассизский, которое найдет себя в сфере выражения человеческой души ${ }^{23}$, уже тихо звучит в сердцах клюнийских чернецов. В пока еще слитном голосе его диспозитива не дифференцированы мотивы и «возрождения», и «реформации», исходящие из религиозных форм правильной жизни.

Оттоновское возрождение обретается вконцеХвека Германией через «всемирность» имперского порыва ее саксонской династии. Диспозитив культурных и образовательных новаций опирается на крупные аббатства и епископства ${ }^{24}$. Соборные и приходские церкви городов формируют сеть августиновских братств - орденов регулярных каноников ${ }^{25}$, берущих начало в 1067 году и немало расплодившихся к XII веку. Их символ «об-

Конкубинат, от concubinatus (лат.) - внебрачное сожительство. Целибат, от caelebs (лат.) - неженатый; caelebs vita холостяцкая жизнь; в данном случае - безбрачие священников. Инвеститура, от in-vestio (лат.) - одевать, облачать; право введения духовных лиц (епископов, аббатов) в должность, передача символов власти; последнее оспаривалось у церкви светской властью.

Дворецкий И.Х. Латинско-русский словарь. С. 226, 142, 553.

23 Бурдах К. Реформация. Ренессанс. Гуманизм. С. 43.

24 История Средних веков. Т. 1. С. 205.

25 Регулярные (уставные) каноники, от canonici regulares (лат.); каноники, которые живут по уставу св. Августина. Каноник - лицо, занимающее церковную должность; например, член капитула - совета при епископе или участник религиозного ордена.

Мак-Ким Дональд К. Вестминстерский словарь теологических терминов. С. $165,166$. новления» отсылал к психическим истокам внутренней природы человека. Он действовал через жертвенную любовь к ближнему и заботу о спасении христианской души.

«Чистая» церковь катар ${ }^{26}$ XI-XIII вв. уповала на возрождение ангельского чина избранных душ. Ее диспозитив включал в себя структуры жизни города и деревни, опирающиеся практически на все социальные слои Италии, Фландрии, Южной Франции; в их числе бедняки, ремесленники, знать, купцы, торговцы. Община «совершеннных» ремесленников и крестьян, созданная в 1176 г. лионским купцом Пьером Вельдо, сформировала диспозитив, территориально покрывавший в течение нескольких веков значительную часть западноевропейского пространства и поныне действующий в современной Италии.

Цистерианское движение, возникшее в конце XI в. в бургундском местечке Сито - Cisterium по латыни в своем «обновляющем» укладе жизни, в своих белых одеждах, исходило из простоты и хозяйственной наличности человеческого пути. Монастырь, заложенный в 1098 г. трудами Роберта Молезмского, дал начало цистерианскому ордену, диспозитивная структура которого к концу XIVв. в европейских странах насчитывала до 700 монастырей ${ }^{27}$. Бернар Клервоский, этот «медоточивый доктор», возглавивший орден в 1115 г., оснастил цистерианский диспозитив «обновления» инфраструктурой папской, юридической и политической власти ${ }^{28}$. Европу наводнили религиозные реликвии крестовых походов дерево, гвозди, кости, истлевшее полотно и мощи. Человеческое источалось из рефлексии о земной природе Христа, из иерусалимских артефактов, транслирующих идею человеческой плоти, - тоже ведь диспозитив, вопиющий о Новом Иерусалиме.

Да и сами по себе крестовые походы (1096-1270) опирались на созвездие религиозных диспозитивов, формируемых из огромной, сумеречной массы простых людей, рвущейся к свету ${ }^{29}$, людей, откликнувшихся на

\footnotetext{
26 К $\alpha \theta \alpha \rho o ́ \varsigma$ - чистый (греч.), в прямом и переносном зна-

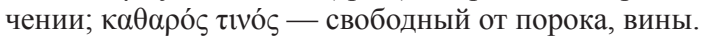

Вейсман А.Д. Греческо-русский словарь. Репринт V-го издания 1899 г. М.: Греко-латинский кабинет Ю.А. Шичалина, 2006. C. 644.

27 История религии: в 2 т. Т. 2 / под общ. ред. И.Н. Яблокова. М.: Высшая школа, 2004. С. 288.

28 Бернар Клервоский был сторонником реформы церкви, третейским судьей в политических и церковных спорах, «серым кардиналом» папской власти, проповедником Второго крестового похода.

Гонсалес Х.Л. История христианства. Т. 1. С. 260, 277.

29 Ле Гофф Ж. Другое Средневековье: время, труд и культура Запада. С. 21.
} 


\section{Философия и психология}

зов воображаемого Иерусалима и стремящихся «подняться» к Господу. Эти простецы полагались в крестовых походах на чудо; однако их чудо, как показали Поль Альфандери и Альфонс Дюпрон, связывалось с надеждами, которые несла идея переселения на Святую землю ${ }^{30}$. Именно идея обновления жизни и правды жизни царила в умонастроениях бедноты, завороженной перспективами христианского эгалитаризма. Христианство позиционировалось через возвышение униженных, через библейское обещание сделать последних первыми. Сакральный статус Святой земли, казалось, давал гарантии такой христианской справедливости уже в этой жизни.

B XI-XII вв. были еще кармелиты и картезианцы, тамплиеры и госпитальеры, бюргеры, бегины и амальрикане, многие другие, диспозитивы которых зрили в сверкающем образе «обновления» свой собственный лик. Однако не за каждым таким видением локализовывался свой диспозитив. Папы Лев IX и Виктор II, Александр II и Григорий VII известны своим реформаторским стремлением к церковному обновлению. Вместе с тем проблематично опосредовать с каждой такой отдельной деятельностью, деятельностью курии или nапских кругов, сфокусированной на образ «renovatio» и структурно компактный диспозитив. Транзитивность отношений папской власти, с папской властью, вокруг папской власти обладает столь подвижным и глубоким проникновением в средневековые социальные структуры, что следование этой транзитивности с неизбежностью приводит к разбуханию и диффузности диспозитивного формирования.

Такое впечатление, что «папский» квазидиспозитив весьма плотно упаковывается в культурное тело эпохи, грезящее о правильных формах жизни. Его реформаторское амплуа как бы везде и мгновенно становится нигде с приходом неудобного понтифика или настырного короля. Отсюда многопапие конца XI - начала XII вв., отсюда Великая схизма на рубеже XIV и XV столетий $^{31}$. Однако, отсюда и IV Латеранский собор 1215 года, решения которому были продиктованы одним человеком - папой Иннокентием III. И решения эти

30 Там же. С. 20.

31 Великий западный раскол (1378-1417), Great Schism

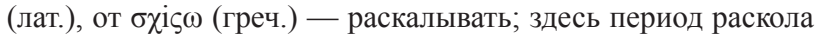
западной церкви, во время которого одновременно правили два-три папы, представлявших противоборствующие римские и авиньонские группировки; термин «Великая схизма» применяется и для события 1054 г. - разделения христианской церкви на Восточную (православную) и Западную (католическую).

Мак-Ким Дональд К. Вестминстерский словарь теологических терминов. С. 334.

Вейсман А.Д. Греческо-русский словарь. С. 1220. опосредовали глобальные ренессансные эффекты будущего - доступные для бедняков школы при каждом соборе, обязательная ежегодная исповедь и пасхальное причащение, бесплатное совершение таинств. Однако в их ряду и такие, как епископская инквизиция, сегрегация евреев и мусульман, принуждаемых теперь к ношению знаков отличия, запрет на театр и развлечения для духовенства.

«Папский» квазидиспозитив кажется неизымаемым из тела более широкой социальной природы и направленности; он суть невыделяемая инкорпорация, рассыпанная в атомы основы. Тот же эффект «неизымаемости» будет демонстрировать диспозитивная ниша феномена, стоящая за образом гуманизма.

\section{Макродиспозитив "Обновление»}

Индикатором социальной продуктивности диспозитивной группы, мобилизованной идеей теистического обновления ${ }^{32}$, стал религиозный подъем XII в., обращенный к интимному, «антропоморфному» пути к Богу. Его фокус - обновление внутреннего человека, обновление нравственное и духовное, идущее от апостольских посланий Павла: «если внешний наш человек и тлеет, то внутренний со дня на день обновляется (2 Кор 4:16), «и не сообразуйтесь с веком сим, но преобразуйтесь обновлением ума вашего» (Рим 12:2). Внешнее, формальное христианство замещяется внутренней христианизацией Европы ${ }^{33}$. И эта субъективизация массового религиозного сознания и духовной жизни составляет решающий мотив к выплескиванию сакраментальной nova vita в профанное бытие. Сакральный образ «обновления», пропущенный через глубины взыскующего человеческого «я», мобилизует не только политическую и социальную жизнь - как это случилось с национальными языками, идентичностями и государствами в конце XIII в., с Кола ди Риенцо в начале $\mathrm{XIV}$ в., - но и художественно-поэтическую сферу, образование, правосудие, науки.

Генри Тод, Рудольф Гильдебранд, Конрад Бурдах по-своему указывали на религиозные диспозитивы, из которых взращивается и проникает в вещи макродиспозитив, который мы называем «Обновление» (семантически точный перевод латинского «renovatio»). Из выстраиваемой здесь схемы диспозитивного генеза следует, что Ренессанс становится «не в противоречие с христианской религией, а из полноты силы религиозного подъема» ${ }^{34}$. Однако для Бурдаха оказывается

\footnotetext{
32 Обновления, опосредованного божественной идеей; от $\theta \varepsilon o ́ \varsigma$ (греч.) - бог.

33 История Средних веков. Т. 1. С. 574

34 Бурдах К. Реформация. Ренессанс. Гуманизм. С. 89.
} 


\section{Психология и психотехника 8(59) • 2013}

важным лишь то, что циркулирует в артефактной форме непосредственно вокруг диспозитивной группы «обновления», т.е. темпорально локализованной в X-XII вв. литературный контекст. Им по сути дела подразумевается артефбактная парадигма трансляции образа «обновление» через религиозные диспозитивы начала второго тысячелетия. Трансляция идет от непосредственной коммуникации с источниками, когда, как замечает Бурдах по отношению к renasci из «Метаморфоз» Овидия, «на протяжении всего средневековья люди почтительно внимали этим гордым и при всей их придворной льстивости волнующим и нас словам» ${ }^{35}$. Аутентичность понимания, однако, требует иметь в виду не только культурный имплант, но и механизмы психического переноса, действующего из глубины веков посредством непосредственного человеческого контакта. Так наследуются вечные темы, так работает габитус Бурдье, так функционирует парадигма «плотной массы», когда смысл образа транслируют не артефакты, а люди, говорящие друг с другом в непрерывности времени и психическом континууме, который покрывает человеческую историю.

Равно так обстоят дела и с «проторенессансными» эффектами, когда в унисон религиозным диспозитивам, вопиющим о nova vita, начинает звучать профанная пестрота. Налицо работа эпистемической функции, зажигающей звезды земной жизни в сакральном образе религиозного «обновления», обмирщающей его и переформулирующей его экзистенциальные вопросы. Религиозные идеи преобразуются в мирское через очеловечивание религиозного чувства, через то, на что свои претензии скоро предъявит гуманизм. Он сделает это сначала в филологической узости; позднее перейдет из библиотечных полок, разделявшихся на divina (теологическое) и humanoria (светское), в духовную образованность, в человеческую природу и станет humanitas - человечностью. И дело здесь не в «явной сублимации религиозного начала Ренессанса», как о том говорит К.А. Чекалов ${ }^{36}$. Конечно, сублимация утраты и боговдохновенной мистики могла сподвигнуть ранних францисканцев - этих «увеселителей Господа» - написать «Цветочки» памяти Джованни Бернардоне ${ }^{37}$, но

\footnotetext{
35 Там же. С. 77.
}

36 Чекалов К.А. Буркхардт и наука о Возрождении // Буркхардт Я. Культура Италии в эпоху Возрождения. М.: Интрада, 1996. С. 11.

37 Джованни Бернардоне - мирское имя св. Фр. Ассизского (1181-1226).

В связи с «сублимацией» можно привести мнение А.А. Клестова из его предисловия к «Цветочкам»: «После смерти св. Фр. Ассизского многие почувствовали невосполнимость утраты и потребность поделиться с другими воспоминани- где ей было взяться у молодого пастуха Джотто, когда тот писал с природы свои? Очевидно, существует разница в степени религиозного пыла людей, работающих в структуре религиозного диспозитства и находящихся вне его непосредственного функционирования. Вазари заметил по поводу Джотто - он «постоянно задумывал и почерпал в природе что-либо новое, он и заслужил то, чтобы быть названным учеником природы, а не других учителей» ${ }^{38}$. Откуда Джотто, «не просвещенный никакой хорошей манерой», черпал порыв подражать природе и рисовать с натуры живых людей, если церковный запрет на изображение профанного человека действовал уже более двухсот лет ${ }^{39}$ ? Человеческая чувственность работ Джотто стимулирована профанным антропоморфизмом культурных практик, формирующих обращенный в «обновление» макродиспозитив. Интерес к человеческому транслировался в «плотной массе» людей и через «плотную массу» людей, выходя из религиозных диспозитивов к Renovatio человеческих дел.

При всей относительности хронометрии культурных периодизаций за XII столетием западноевропейской истории признается особое значение. Блок пишет, что здесь после скрытого глубинного вызревания проявляет себя эпоха могучего культурного расцвета, о котором нередко говорят как о «возрождении XII в.» ${ }^{40}$. Это эпоха «средневекового гуманизма», «средневекового ренессанса» ${ }^{41}$. Это, по словам Ле Гоффа, «великий поворот», когда наступают решительные изменения

ями об учителе. ... «Цветочная» литература в глазах средневекового читателя является ... наиболее художественной и индивидуализированной. ... Эта литература вырастает снизу, из простого рассказа о подвиге св. Франциска, как ответ на духовные запросы каждого отдельного брата или просто верующего». Содержание «цветочной» литературы — деяния св. Франциска и его «братьев».

Клестов А.А. Предисловие // Цветочки славного мессера святого Франциска и его братьев. СПб: Журнал «Нева»; Издательско-торговый дом «Летний сад», 2000. С. xxii, xxix, vii.

38 Вазари Дж. Жизнеописания наиболее знаменитых живописцев, ваятелей и зодчих: в 5 т. Т. 1 / пер. А.И. Венедиктова. M.: TEPPA, 1996. С. 314.

Труд Джорджо Вазари (1511-74) «Жизнеописания...» вышел в 1550 году (второе издание - 1568 г.).

Джотто ди Бондоне (1266/67-1337) — «сын хлебопашца и человека простого» - в «живом» стиле писал для религиозного диспозитива, однако, судя по его жизенописанию, внутренне имел к нему весьма опосредованное отношение.

39 Там же. С. 313, 302.

40 Блок М. Феодальное общество // Блок М. Апология истории, или Ремесло историка / пер. с франц. Е.М. Лысенко. М.: Наука, 1986. С. 181, 164.

41 История Средних веков. Т. 1. С. 550. 


\section{Философия и психология}

в структурах сознания западного человека ${ }^{42}$. Здесь, замечает Г.К. Косиков, «в результате начавшегося процесса умственной дифференциации светская культура стала отделяться от церковной» ${ }^{43}$. Внешние формы жизни стимулируют к рефлексии над собственным «я». Религиозные диспозитивы nova vita, изживая себя, заняты интенсивным производством этих внешних форм, которые они вбрасывают в жизнь профанного человека. Так диспозитив Обновления формируется в профессиональных коллективах купца, ремесленника, пролетария, университетского профессора, юриста, художника, скульптора, etc.

Исповедальные практики в XII веке выходят за пределы монастырских стен и распространяются в миру ${ }^{44}$. Они назойливо вычерчивают в индивиде путь к его самости, решительно берутся за его индивидуацию - установление дорог к самому себе. Эта юнговская индивидуация получает в 1215 г. высочайшую санкцию IV Латеранского собора - обязательное и ежегодное соблюдение церковных таинств индивидуального покаяния и пасхального причастия. Позднее V Латеранский собор (1512-1517), утверждая индивидуальность каждой души, стимулирует процесс автономизации сознания. Понуждая к регулярномy рефлективному впадению в себя, оснастив дотошным инструктажем «психоаналитическую» практику клира, западное христианство, оттолкнувшись от юнговской индивидуации, создает культ индивидуализма, в котором по-монашески (какой возврат!) обособится от мира убежденная в своей исключающей ценности западноевропейская личность.

Интенсификация религиозного самоуглубления в XII в. дает ощущение индивидуальности в Творении; его следствие, отмеченное Л.П. Карсавиным, - обострение душевной жизни средневекового человека. Интенсивные евангелические проекции вочеловечивают образ Христа, приближают к земному, обволакивают интимной, задушевной религиозностью ${ }^{45}$. Однако, этот близкий человеку Христос и духовные переживания его человеческой жизни ${ }^{46}$ неизбежно запускают механизм контрпроекции, примеряющий божественное к мирско-

42 Ле Гофф Ж. Другое Средневековье: время, труд и культура Запада. С. $38,45$.

43 Косиков Г.К. Средние века и Ренессанс. Теоретические проблемы // Методологические проблемы филологических наук. Сборник научных трудов. М.: Изд-во Московского университета, 1987. С. 233.

44 Блок М. Феодальное общество. С. 167.

45 Карсавин Л.П. Культура Средних веков. М.: Книжная находка, 2003. С. 190, 149.

46 Ле Гофф Ж. Другое Средневековье: время, труд и культура Запада. С. 192. му, судящий приватное, требующий земного оправдания. С ним рождается человеческая мерка мира и себя в мире, пока еще не та индивидуально исключающая из коллектива мерка, но самоопределяющая в нем, иными словами, антропоцентрирующая мерка. Когда Ле Гофф говорит, что, начиная с XII в., Христос шире распахнул свои объятия человеку ${ }^{47}$, Карсавин фиксирует в этом существеннейший момент в процессе творческого $c a$ моразложения средневекового общества ${ }^{48}$.И появление здесь индивидуального портрета, реалистической иконографии есть не только свидетельство возникновения нового чувствования, замеченного Ле Гоффом ${ }^{49}$, но в значительно большей степени индикатор тектонической культурной трансформации, которая суть замещение культурной доминанты религиозной диспозитивной группы встающим на ее место макродиспозитивом Обновления. И то, что это действительно замещзающий диспозитив, читается в генерируемой им культуре XIIXIII вв., которая видится «своеобразным и пестрым, но внутренне единым ... изелым ${ }^{50}$.

Эпистемическая схема замещения дает нам возможность ощутить диспозитивный характер изменений в «осени средневековья», звучащий в формуле Йохана Хейзинга: «Новое приходит как ... внешняя форма до того, как оно становится действительно новым по духу» ${ }^{51}$. Дух возрождения, витающий в «ренессансной» эпохе XII-XIII вв., станет дыханием жизни для времени Rinascita ${ }^{52}$. Диспозитив последнего обособится в результате эффекта расщепления макродиспозитива Обновления, тем самым обретя преемственность «ренессансности», которая войдет в его плоть и кровь.

Конечно, Ле Гофф вправе заключать, выделяя XII в., что «вклад церкви в этот подъем христианского мира был одним из главных» ${ }^{53}$. Однако то новое, что приходит в средневековую «осень» пока как внешняя форма, не ограничивается рамками религиозного существования. Именно с XII в. под властью диспозитива Обновления начинается еще один процесс замещения - в створ

\footnotetext{
47 Там же. С. 192.

48 Карсавин Л.П. Культура Средних веков. С. 193.

49 Ле Гофф Ж. Другое Средневековье: время, труд и культура Запада. С. 192.

50 Карсавин Л.П. Культура Средних веков. С. 179 (курсив мой).

51 Хейзинга Й. Осень Средневековья. Исследование форм жизненного уклада и форм мышления в XIV и XV вв. во Франции и Нидерландах / Пер. с франц. Д.В. Сильвестрова. М.: Наука, 1988. С. 355 (курсив мой).

52 Возрождение (итал.).

53 Ле Гофф Ж. Цивилизация средневекового Запада // Пер. с франц / под общ. ред. В.А. Бабинцева. Екатеринбург:
} У-Фактория, 2005. С. 101. 


\section{Психология и психотехника 8(59) • 2013}

религиозного понимания жизни вступает ее мирская судьба - процесс, идущий с тех пор с переменным успехом. К середине XI в., когда были изжиты последствия нашествий арабов, мадьяр и норманнов, глубокие и всеобщие изменения, изменения всей системы человеческих отношений, дали начало второму, в периодизации Марка Блока, феодальному периоду ${ }^{54}$.

То полемическое самосознание, которое находит Гарэн в итальянском кватроченто (XV в. $)^{55}$, существует и как эпифеномен «григорианской реформы» второй половины XI в. - внутрицерковного реформационного движения, начало которому было положено папой Григорием VII (1073-1085) ${ }^{56}$. В полемическом пылу, питавшемся renovatio религиозных диспозитивов, на площадях и в кабаках Европы яростно судили о целях государства, правах короны, народов и пап. И повсеместно, как отмечает Блок, эти спорящие речи оказывали свое действие ${ }^{57}$. Мышление, освобождаясь от прецедентной логики «примеров», дерзало к истолкованию и проблематизации жизни. Схоластика оснастила страсть к суждению и осмыслению рациональной рефлексией, логическим схематизмом, интеллектуальной ответственностью. Образованность в течение XII в. делает огромные успехи ${ }^{58}$. Диспозитив Обновления транслирует эту новую культуру мысли, производя интеллектуальный ренессанс эпохи. Точное мышление царит в строительстве церковных сводов ${ }^{59}$; познавательный энтузиазм исходит из растущей сети городских школ, библиотек, становящихся университетов; книги делаются инструментом познания и, вместе с тем, предметом массового производства и торговли ${ }^{60}$.

Диспозитив Обновления мобилизует людей действия, которые обретают теперь более совершенный, чем прежде, инструмент логического анализа ${ }^{61}$. Через них он располагается на верфях, увеличивая тоннаж судов и внедряя архиштевнь; в производстве, модернизируя прялки, водяные мельницы и конструируя ветряные; в сельскохозяйственных угодьях, возделывая новые земли, изобретая удобную упряжь, борону и асимметричный плуг. Диспозитив Обновления про-

54 Блок М. Феодальное общество. С. 123, 242, 134.

55 Гарэн Э. Проблемы итальянского Возрождения. Избранные работы. М.: Прогресс, 1986. С. 34, 38.

56 Мак-Ким Дональд К. Вестминстерский словарь теологических терминов. С. 98.

57 Блок М. Феодальное общество. С. 169.

58 Там же. С. 166.

59 Там же. С. 123.

60 Ле Гофф Ж. Цивилизация средневекового Запада. С. 100.

61 Блок М. Феодальное общество. С. 170. никает в быт, распространяя там бани и диеты, изобретает очки. В экономике он выдает кредит, оживляет торговый обмен, штампует золотой флорин («монетный ренессанс» XIII в.). В зодчестве использует камень и архитектурный расчет, производит вновь стекло, инвестирует в готику - эту «французскую манеру» проторенессансного самовыражения. И наконец, этот новый диспозитив изменяет рецепиию жизни, когда включает в ее художественный оборот масло живописцев, глубину перспективы, литературную прозу и певческую полифонию. К концу XII в. поразительный расцвет искусства сочетается с новым качеством документа, который становится более подробным, более точным, более организованным по содержанию. Это время «взаимопроникновения священных и мирских сюжетов» ${ }^{62}$. Это время кристаллизации и тотального расширения диспозитива, живущего под эпистемическим знаком культурного обновления.

Диспозитив Обновления отвоевывает у церкви само время, символизируя тем самым, что время обновления религиозных диспозитивов прошло. С XIV в. рабочие колокола и механические башенные часы точно ведут профессиональный хронометраж, который приходит на смену религиозным и сельскохозяйственным ритмам $^{63}$. Коммерческая претензия на время и знание, которые раньше принадлежали лишь Богу и не могли служить наживе, с XIII в. начинает получать церковное оправдание ${ }^{64}$. Купец теперь «по-совести» торгует временем, используя кредит и экономическую конъюнктуру (перепродажа в благоприятные моменты), равно как и университетский профессор «по-совести» взимает плату со средневековых студиозов ${ }^{65}$. Теологическая казуистика в своей «гибкости» сополагает увеличение состояния с замыслом провидения, тем самым морально совмещая цели, преследующие барыш и спасение. «Время - деньги» становится мерилом добродетели, часы ее символом, который охотно использует новая иконография XIV в. ${ }^{66}$ Расчетливая мораль и скупая набожность найдут свою надежную опору в приближающемся протестантизме.

Так сформировался и сложился в социальной структуре средневековья замещающий его религиозную узость диспозитив Обновления. Разные люди всматривались в эпистемическую вещь «renovatio», которая символизиро-

\footnotetext{
62 Там же. С. 122, 169.

63 Ле Гофф Ж. Другое Средневековье: время, труд и культура Запада. С. 52-54.

64 Там же. С. 37, 46.

65 Там же. С. 86.

66 Там же. С. $45,57$.
} 


\section{Философия и психология}

вала его весьма синкретичное и поэтому относительное единство. Культура XV, XVI вв. уже живет в сознании того, что родилась новая эпоха ${ }^{67}$. Сознание это имеет свою диспозитивную ретроспективу и, вместе с тем, свою программу расставания с «неуклюжестью» средневекового прошлого. Замена типа культуры, тем не менее, наступает здесь не как разрыв, но через замещзающий диспозитивный генез, который опосредуется церковью и группой диспозитивов, опирающихся на религиозную инфраструктуру ${ }^{68}$. Всей своей чувственностью, теистическим антропоморфизмом, всеми своими реновационными надеждами это «священное» сообщество располагает ростки диспозитива Обновления в теле широкой социальной природы. Мобилизуя социальные практики к созиданию обновляющих надежд, оно ткет его неизбежную судьбу быть расщепленным в Ренессанс и Реформацию, инкорпорировать Гуманизм и вылелить в своем печальном исходе экстравагантную мысль социальной утопии.

\section{Двучастный символ: прелюдия к расщеплению}

Диспозитив Обновления расщепляется не только по кромкам социальных структур, локализующих культурные практики в рамках новых доктринальных программ; его раскол содержательно глубже. Раскол этот духовной, психической природы, скрепленной с архитектоникой истории общественного человека. Расщеплению подвергается мощный имплант культурной памяти и социального опыта. Его эпистемические наслоения образуют структуру осмысления и руководства жизнью, наследованные человеком и его коллективами. Набросок латентных дифференциаций в теле диспозитива Обновления мы выполним в контекстах библейских сюжетов и социальных религиозных практик.

67 Гарэн Э. Проблемы итальянского Возрождения. С. 34.

68 Жак Ле Гофф отмечает такие важные с точки зрения диспозитивного генеза церковные деяния, как усовершенствование измерения времени для нужд церковного календаря; строительные инновации, идущие от возведения храмов; модернизацию сельскохозяйственной техники монашеских орденов для обеспечения расширяющейся раздачи продовольственной милостыни. Социально обновляющее значение последнего может быть оценено исходя из объема преобразований - европейской церкви принадлежало до $1 / 3$ всей обрабатываемой земли.

Ле Гофф Ж. Цивилизация Средневекового Запада. С. 242.

Парижский университет, основанный около 1200 г., характеризуется В.Л. Задворным как «метрополия христианской науки». Основным фактором его возвышения «стала постоянная забота об университете римских пап, их стремление сделать из него форпост теологии».

Задворный В.Л. Святой Бонавентура и его эпоха // Бонавентура. Путеводитель души к Богу. М.: Греко-латинский кабинет Ю.А. Шичалина, 1993. С. 5, 6.
Культурные практики, мобилизованные диспозитивом Обновления, способны принять разные русла, когда доминанта его эпистемического символа указывает на внешний или на внутренний мир личности. Первое в большей степени концентрируют культурные практики диспозитива Реформации, второе - Возрождения. К XIV в. психокультурная двучастность набирает силу, локализуясь, с одной стороны в движениях политического и церковного устроения, а с другой - в сферах духовного производства. В Италии и Германии этого периода религиозно-институциональная и нравственно-человеческая стороны обновления понимаются «более жизненно по сравнению с чисто догматической их формулировкой». Немецкие и нидерландские церковные реформаторы используют образ "ренессанса» в отношении религиозного обновления ${ }^{69}$. В библейских текстах такая двусторонняя рефлексия осуществляется через ряд взаимопереходящих образов спасения, крещения, творения, воскрешения, очищения, омоложения, etc. Их толкования опираются на близкие по смыслу выражения renasci, regeneration, nova vita, renovatio, reformatio, которые перетекают друг в друга в контекстах священных повествований ${ }^{70}$.

Историко-филологическое исследование К. Бурдаха показывает определенного рода единство существовавшего все средневековье двучастного образа, в котором проявляются понятия «Реформация» и «Ренессанс» ${ }^{71}$. Таким образом фиксируется двусторонность символа, репрезентирующего эпистемическую вещь «обновление». Основу единства в нашем случае составляют библейские тексты, в которых идеи обновления религиозных коллективов и человека, внешней и внутренней его жизни, объединяются смысловой целостностью развивающихся нарративов.

Влияние Священного писания на средневековое общество было тотальным; его голос звучал в ушах всех дышащих, он проникал в сердца всех чувствующих. В евангелистической метафорике эта двусторонность функционально отнесена к когнитивным способностям индивида. В Послании к римлянам, писанном около 59 г., св. апостол Павел призывает их к разумному служению. Реализуемое в контексте духовной деятельности такое служение имеет двучастное целостное содержание: «И не сообразуйтесь с веком сим, - назидает он, - но преобразуйтесь обновлением ума вашего» (Рим 12:1-2). Внешняя критика мира и отказ от его неправильных форм жизни сливаются здесь с изменением внутреннего строя личности. Такое обновление функционирует как

\footnotetext{
69 Бурдах К. Реформация. Ренессанс. Гуманизм. С. 42, 186.

70 Там же. С. 36-39.

71 Там же. С. 33, 50.
} 


\section{Психология и психотехника 8(59) • 2013}

преобразование через духовное познание, конституируя новозаветного индивида. Суть призыва ап. Павла: «Станьте новыми людьми!», прозвучавшего между 61 и 63 гг. в его Послании к ефесянам, - «отложить прежний образ ветхого человека, ... обновиться духом ума ... и облечься в нового человека» (Еф 4:22-24) ${ }^{72}$. Отсюда вырисовывается трансформационный тренд диспозитива Обновления, который латентно присущ ему в разных культурных условиях функционирования, - предстоящее расщепление обусловлено дифференцированными локализациями в социальной структуре внешних и внутренних интенций коллективов как религиозных, так, конечно, и светских. Распад сложился по линии «нового человека», поскольку каждый вкладывал в зону его ответственности свое.

Интенция во внешнее - земное или потустороннее представлена картинами обновления структур жизни и обретения иного бытия. Христос обновляет лицо земли (Пс 103:30) и очищает Церковь, «чтобы представить ее Себе славною Церковью», не имеющей ни пятна, ни порока (Еф 5:25-27). Незримое соединение с судьбой Христа через таинство крещения ${ }^{73}$ дает «и нам ходить в обновленной жизни» (Рим 6:4), увидеть новое небо, и новую землю, и святой город Иерусалим, где «сказал Сидящий на престоле: се, творю все новое» (Откр 21:1).

Внутреннее преобразование свершается в духовной сфере посредством церковных таинств или как акт непосредственного обновления личности. Таинства дают гарантированный кредит духовной чистоты. В крещении этот кредит налагается силами Святого Духа, опосредуясь «банею возрождения и обновления» (Тит 3:5) $)^{74}$. Но свершившееся в нас, замечает Августин, должно быть нами сохранено ${ }^{75}$. И этот августиновский

72 Чтобы проиллюстрировать результаты филологических исследований К. Бурдаха, отметим, что Послание к римлянам в выражении «обновлением ума» использует слово «reformamini» (Рим 12:1-2), а Послание к ефесянам в выражении «обновиться духом» - слово «renovamini» (Еф 4:2224). Подобная двучастная схема звучит, например, в Посланиях к коринфянам - «Итак, кто во Христе, тот новая тварь; древнее прошло, теперь все новое» (2 Кор 5:17), а также в (1 Kop 2:15-16), (2 Кop 4:16), etc.

Бурдах К. Реформация. Ренессанс. Гуманизм. С. 37, 38.

73 Крещение здесь уподобляется процессу умирания и возрождения; смыкание вод над головой знаменует погребение Христа, а новый выход в свет - его воскрешение. Догматическое определение крещения - «таинство возрождения» (sacramentum regenerationis, лат.).

74 Полностью этот новозаветный фрагмент из Послания к Титу св. апостола Павла звучит так: «Он спас нас не по делам праведности, которые бы мы сотворили, а по Своей милости, баней возрождения и обновления Святым Духом».

75 Блаженный Августин. Об упреке и благодати. С. 227. принцип личной ответственности имел далеко идущие последствия ${ }^{76}$. Следует заметить, что формула «баня возрождения» использовалась еще в языческих мистериях как принятие духовного обновления, исходящего от божества ${ }^{77}$. В таинстве евхаристии посредством покаяния достигается индивидуализаиия благочестия. Однако в непосредственном - активном пространстве обновления душа сама должна дать плод свой, должна растить дела по "роду своему» ${ }^{78}$. О таком внутреннем духовном росте, о таком личностном перевороте Иисус говорил Никодиму-фарисею, одному из начальников иудейских, - «если кто не родится свыше, не может увидеть Царствия Божия» (Ин 3:3).

Двучастность идеи религиозного обновления внешнего и внутреннего мира имеет ввиду одно - христианское спасение. Евангелическая настойчивость к спасению воспринимается как дело земной жизни, оно предмет задачи не только Бога, но и индивида. В основу ставится стратегия человеческих усилий, соотнесенная с Божественной благодатью и оформляемая ей ${ }^{79}$. Трактат Августина «Об упреке и благодати», писанный в 426-427 гг., репрезентирует церковную рефлексию, которая ведет «спасение» к человеку. Человек свободен решать сам; во зле он свободен от праведности, добро же всегда санкционировано Христом, поскольку без благодати Его человек не способен опознать, что есть добро. Действуя во благо без благодати, человек имеет последствия злые, неправедные. В своем нравственном возрождении он должен просить Его: «Стань помощником моим и не отступай от меня». Этой благодатью от Того, кто взращзивает в тайне, «единственно освобождаются люди от зла». Они обретают вдохновение доброй воли и дел, т.е. своего рода двучастность благодати во внутреннем и внешнем. Но это воздействие Духа Божьего «для того, чтобы сами действовали, а не для того, чтобы сами ничего не делали». Отсюда наслаждение праведностью, когда «земля их дала плод свой» ${ }^{80}$.

Августиновское аргументирование демонстрирует логику, через которую религиозное проникает в социальное, настраивает его и вместе с тем обмирщается так, что религиозный стимул становится мирским этосом,

\footnotetext{
76 Для описания преображения внутреннего человека Августин использует термин «renovatio». Бурдах К. Реформация. Ренессанс. Гуманизм. С. 41.

77 Баня возрождения, омовение возрождения — lavacrum regenerationis (лат.).

78 Блаженный Августин. Исповедь / пер. с лат. диак. А. Гумерова. М.: Изд-во Сретенского монастыря, 2007. С. 417, 419.

79 Уивер Р.Х. Божественная благодать и человеческое действие: исследование полупелагианских споров / пер. с англ. А.В. Кырлежева. М.: Центр библейско-патрологических исследований; Империум Пресс, 2006. С. 11.

80 Блаженный Августин. Об упреке и благодати. С. 218, 219.
} 


\section{Философия и психология}

конституирующим нормативные структуры, и доктринальной установкой, направляющей деятельность. Диспозитивная функция этоса и доктрины поначалу не столько управлять, сколько определять институты и коллективы приверженцев. Взаимное опознание строит социальные сети, синхронизирует социальные практики, дает приращение диспозитивному телу. Оно же поляризует инструменты спасения в направлении одной из двучастностей - внешней или внутренней.

Однако откуда берется духовная сила у послеримского депрессированного индивида, этого средневекового Иова; откуда берется сила избыть в себе стратегию дарованной благодати, оправдывающей непротивление обстоятельствам?

Средневековое царство верующих представляло себя коллегией избранных, которые приняли могучий дар пребывания в вере до конияа и которых никто и ничто, как кажется, не может отлучить от любви Христовой - ни скорбь, ни теснота, ни гонения, ни меч, ни глад и ни смерть ${ }^{81}$. Помнили они слова Его прощальные: «Я с вами во все дни до скончания века» (Мф 28:19), и завет быть сынами Его света, ведь «ходящий во тьме не знает куда идет» (Ин 12:3536). Им казалось, что они «уже принадлежат Богу», «будучи с непоколебимой твердостью записаны в памятную книгу Отца своего.... но не таковы они для Бога», они - хранящие призрачную праведность ${ }^{82}$. Поэтому сказано было им - «со страхом и трепетом совершайте свое спасение». Такое средневековье еще на территории Иова. Дни его «бегут скорее челнока и кончаются без надежды», жизнь его - одно дуновение, когда ищет оно впотьмах милосердного Бога. Тогда Бог скорее страж человека, лежащего в прахе, «завтра поищешь меня, а меня нет» (Иов 7:6-7, 20-21). И чего они достигли, в том стали и ходить ${ }^{83}$. «Ибо Он извлекает из сети ноги мои» (Пс 24:13).

Проблема Средневековья - спасение из царства Иова, его инструмент - трансформация идеи христианского спасения, обладающей огромной духовной силой. Она по-разному берет людей: через обстоятельства, случай, но более всего - сочетаясь незримыми узами с психическим строем мобилизуемых коллективов. Последнее не столько эпифеномен культурогенеза, сколько результат психогенеза общественных групп. Блок вскользь заметил, что психология массового сознания - один из отправных пунктов для историка социальной структуры ${ }^{84}$. Средство изжить средневековую депрессию, состояние вопиющего во страхе

\footnotetext{
81 Там же. С. 231.

82 Там же. С. 236.

83 Блаженный Августин. Письмо 217-е. К Виталию Карфагенскому // Блаженный Августин. Антипелагианские сочинения позднего периода. С. 284.

84 Блок М. Феодальное общество. С. 122.
}

Иова, конструировалось психогенезом в семиотическом ключе. Символ потустороннего спасения насыщался в лике эпистемической вещи «обновления» знаками земного служения, дающего, конечно, пусть и в некой «дурной» транзитивности залог индивидуального воскрешения. Сакральное передавало свою духовную ауру и мощь новому репрезентамену. Страсть до жизни брала свое. Иэту страсть наделил побуждающей силой диспозитив Обновления, который транслировал ее символические значения мощью всех своих религиозных и светских коллективов.

Люди перестали ждать благ от небесных щедрот, . . или устали ждать. Они переиначили небесное благо на земное, но с тем возросла их охота до казуистических игр с мирским. Их эпистемические пути радикально разделились, одни искали свое благо в себе, другие - в социальной структуре. И блага эти стали их земным «спасеньем», за которым робко следовало небесное. С тех пор их дуальная земная вера, размножавшись в вариациях, стала оправданием их смерти. Здесь устанавливается не только авероистическая дифференциация истины на истину философскую и истину откровения. Здесь диспозитив Обновления обмирщает логику спасения. Последующее реформационно-ренессансное его расщепление становится инструментом двучастной дифференциации логики спасения, внутренняя и внешняя ипостаси которого профанируются в мирском. Процесс этот заострил полюса европейской ментальности и поляризовал ее эпистемические практики. И в этом нашла себя эпистемическая судьба Средневековья.

Мирская страсть, приняв сакральные стигматы религиозной предшественницы, придала делу христианского спасения особую ментальную строптивость. Гарэн маркирует ее как полемическое самосознание, неизвестно откуда взявшееся ${ }^{85}$. Однако, психокультурная проблема здесь гораздо серьезнее. Новое время в обмирщенном христианстве наступает на четыре века раныше его светского vis-a-vis. Индикатором перемен стал интеллектуальный фанатизм к мирским свершениям. В новые светские времена он будет оружием ученых. Осенью средневековья это наследие раннехристианского энтузиазма, стучавшегося во врата Бога, входят в арсенал «ренессансной» личности. Теперь человек стучался в земные врата. Он ставил дело спасения на практическую основу как во внешней, так и во внутренней его двучастности. Духовный трепет замещается душевным волнением; им вооружает новые диспозитивы филологический гуманизм. «Бог в присядку» - в этом скрытое удивление входящего на страницы «Города Солнца», «Новой Атлантиды» или «Талемской обители». В новейших временах этот бог выкидывает коленца в ритмических напевах приплясывающих в церквах конгрегаций.

85 Гарэн Э. Проблемы итальянского Возрождения. Избранные работы. С. 34. 


\section{Психология и психотехника 8(59) • 2013}

Кампанелла, Бэкон, Рабле и иже с ними - все они, «обновленные умом», в строгом следовании новому символизму апостольских предписаний, культивировали жилку предприимчивости к своему спасению. Расчетливые калькуляторы земного счастья исчисляли его как Леонардо в пропорциях художественных тел и механических фигур или как Мор в скрупулезных подробностях и регламентациях жизни пятидесяти четырех городов славного короля Утопа. Конечно, был еще божественный Рафаэль, но и он был охоч до счета, правда дензнаков папского достоинства. Кажется, новый христианский человек не считает себя «новым». Он апеллирует к моделям античности, которые на деле стали лишь техническим подспорьем для высказывания своего, стимулом, - как заметил Лоренцо Валла, для своего рода состязания ${ }^{86}$.

Новый христианин лукаво лицемерит; в действительности он не нуждается ни в ком, кто «указал бы ему, как подражать «своему роду» ${ }^{87}$. Отсюда жесткий ригоризм и реформаторов, и гуманистов XIV-XVI вв. Отсюда страстные инвективы Франческо Петрарки к естествознанию и медицине, к этим глупцам, рыщущим до природы вещей и верящим, что зажали небо в своем кулаке. Отсюда презрительный тон философов, объявивших, что «новые», т.е. предшественники их, ученые XIII-XIV вв., «довели «варварство» в праве, философии, риторике, языках и искусстве до крайнего предела». Отсюда проклятия их стилю архитектора Филарета (Антонио Аверлино), фантазера, изумившего современников описанием идеального чудо-города-государства $^{88}$. Дискурсивные стратегии репрезентируют здесь казуистические игры, ведущиеся во имя разрыхления старого, сквозь которое нужно расти. Это действительно казуистика, исключавщая предшественников, современников-естественников и апеллировавшая к древним. Достаточно вспомнить про ученый оккультизм Парацельса - философа, алхимика и врача из XVI в. или ортодоксальных богословов XII в., называвших, подобно гуманистам, практические науки - математику и механику - «прелюбодейными» ${ }^{89}$. Г.К. Косиков, имея ввиду спектральность менталитета, говорит, что «XVI в. вполне можно было бы назвать эпохой Магии и Натурфилософии» ${ }^{90}$.

\section{6 Там же. С. 39.}

Лоренцо Валла (105/07-1457) — итальянский философ, доказал фальсификацию «Константинова дара».

87 Блаженный Августин. Исповедь. С. 428.

88 Гарэн Э. Проблемы итальянского Возрождения. Избранные работы. С. $38,45$.

89 История Средних веков. Т. 1. С. 596.

90 Косиков Г.К. Средние века и Ренессанс. Теоретические проблемы. С. 230.
Таким образом, казуистические игры, ведущиеся во славу обновления, репрезентировали в большей степени не духовный, но диспозитивный раскол с ближайшим прошлым, коллективы которого, стоящие за такими именами как Роджер Бэкон, Аквинат, Гроссетест, Витело, Оккам, Буридан, Орем, были выведены в эпистемическую периферию. Дело шло к разрыву с материнским диспозитивом Обновления.

Было неоднократно замечено - то, что пришло с Реформацией и Ренессансом, есть результат постепенных культурных преобразований и медленной секуляризации ${ }^{91}$. Диспозитивный генез дает здесь свою модель культурной трансформации. Процесс формирования идет в русле локализации культурных практик, формирующих соответствующие протодиспозитивные области в материнском теле диспозитива Обновления. Эпистемическая функция, ведущая дело к расщеплению, опирается на психогенез обмирщенной социо-религиозной двучастности, поляризующей коллективную ментальность в дихотомии внешнего-внутреннего спасения. Последнее, конечно, латентно, но от этого не менее действенно. Классический пример такой поляризации дают «истории» Иоахима Флорского и Франциска Ассизского, общественное служение которых стало индикатором работы формирующихся диспозитивов. Человеческие коллективы, обратившие эти имена в эмблему собственной подвижнической деятельности, начали процесс культурного разделения и внутренней синхронизации задолго до зафиксированного историками реформационно-ренессансного разрыва.

Последователи Иоахима (1132-1201) в двучастном выборе - реформация внутреннего человека или обновление церкви - предпочитали последнее. В XIII в. до государства Святого Духа, о котором в хилиастической перспективе писал калабрийский пророк, было рукой подать. Его концепция казалось весьма убедительной для средневекового человека ${ }^{92}$. В ту последнюю эпоху человеческой истории, которая должна взять отсчет с 1260 г. от Рождества Христова, «не будут царствовать более над народом Господа цари высокомерные и оскверненные мерзостью идолов». Церковь ждут «родовые мучения» и очищение «от всяческих плевел». Ибо стяжательство их «есть служение идольское» и царства их «будут сокрушены и уничтожены» ${ }^{93}$. Конечно, по-

91 Блок М. Феодальное общество. С. 122, 123; История Средних веков. Т. 1. С. 630, 631; Бурдах К. Реформация. Ренессанс. Гуманизм. С. 89.

92 Задворный В.Л. Святой Бонавентура и его эпоха. С. 13.

93 Флорский Иоахим. Согласование Ветхого и Нового Заветов / пер. с лат. М.Я. Якушкина // Антология средневековой мысли (Теология и философия европейского Средневековья): в 2 т. Т. 1 / под ред. С.С. Неретиной. СПб: Изд-во Российского христианского гуманитарного института, 2001. С. 526, 527. 


\section{Философия и психология}

участвовать в сокрушении и войти в орден праведных пожелали многие. Ле Гофф говорит, что многочисленные инсургенты из числа клира и мирян брали из иоахимизма в первую очередь антиклерикальные, антифеодальные и эгалитаристские пророчества ${ }^{94}$. Начиная с середины XIII в. происходят ужасающие церковные, политические и социальные столкновения ${ }^{95}$.

Франциск Ассизский (1181-1226) мирской ярости иоахимизма предпочел иное - жизнь заостренную во внутреннего человека; благочестие, избегающее социальных структур; духовную поэтику, изливавшуюся в проповеди; судьбу, сближающую совесть попутчиков. Его тирическое cogito, будучи в заботах о земном человеке, несло страх божественного и трепет мирского. Его апостольская община - эти «увеселители Господа», подписавшиеся в услужение госпоже Нищете, - переросла скоро в Орден братьев меньших - миноритов. Последний не долго следовал по стопам родителя. Конвентуалы отстроили совсем не нищее монастырское царство, спиритуалы омылись кровью иоахимизма. Однако те, кто говорят, что Франциск протягивает руку гуманизму, должны все-таки иметь ввиду, что этот сибаритствующий гуманизм вряд ли встретит крепкое пожатие его искренней десницы. Вместе с тем ножницы ценностей не мешают ранней францисканской литературе XI-XIII вв. в лице Бонавентуры, Данте Алигьери, Раймонда Луллия оказывать решающее влияние на ренессансное искусство и новую духовную литературу Европы ${ }^{96}$. В ряду францисканцев - Франческо Петрарка и Франсуа Рабле. В диспозитиве Обновления францисканцы наряду с деятельностью в литературе и искусстве формируют образовательные сети кафедральных школ и университетов. Все это позднее локализуется в ренессансный диспозитив.

Иоахим, конечно, не рассчитывал, что путь в Царствие небесное будет выстлан кровавыми бунтами его почитателей, впрочем как и многие «праведники» после него. Но и Франциск не мог предвидеть инквизиторских мерзостей францисканцев - этих Domini canes, «псов Господних», человеколюбие которых воплотилось в поцелуе «Железной девы», Испанском сапоге, водяных пытках; последние и в наши дни - любимое занятие заокеанских инквизиторов. То же ведь «увеселители Господа». Пусть деятельной Марфы и путь созерцательный Марии равно вел в человеческий тупик.

Продолжение в следующем номере

\section{Список литературь:}

1. Бахмутский В.Я. На рубеже двух веков // Спор о древних и новых. М.: Искусство, 1985. С. 7-40.

2. Блаженный Августин. Исповедь / Пер. с лат. диак. А. Гумерова. М.: Изд-во Сретенского монастыря, 2007.448 с.

3. Блаженный Августин. Об упреке и благодати // Блаженный Августин. Антипелагианские сочинения позднего периода / Пер. с лат. Д.В. Смирнова. М.: АС-ТРАСТ, 2008. С. 217-272.

4. Блаженный Августин. Письмо 217-е. К Виталию Карфагенскому // Блаженный Августин. Антипелагианские сочинения позднего периода / пер. с лат. Д.В. Смирнова. М.: АС-ТРАСТ, 2008.С. 273-298.

5. Блок М. Феодальное общество // Блок М. Апология истории, или Ремесло историка / Пер. с франц. Е.М. Лысенко. М.: Наука, 1986. С. 122-181.

6. Бодрийяр Ж. Система вещей / пер. с франц. С.Н. Зенкина. М.: Рудомино, 1995. 174 с.

7. Бурдах К. Реформация. Ренессанс. Гуманизм / пер. с нем. М.И. Левиной. М.: Российская политическая энциклопедия (РОССПЭН), 2004. 208 с.

8. Буркхардт Я. Культура Италии в эпоху Возрождения / пер. с нем. А.Е. Махова. М.: Интрада, 1996. 528 с.

9. Вазари Дж. Жизнеописания наиболее знаменитых живописцев, ваятелей и зодчих: в 5 т. Т. 1 / пер. А.И. Венедиктова. М.: ТЕРРА, 1996. 608 с.

10. Вейсман А.Д. Греческо-русский словарь. Репринт V-го издания 1899 г. М.: Греко-латинский кабинет Ю.А. Шичалина, 2006. 1371 с.

11. Воробьев Л. Утопии и действительность // Утопический роман XVI-XVII вв. М.: Художественная литература, 1971. С. 5-38.

12. Гарэн Э. Проблемы итальянского Возрождения. Избранные работы. М.: Прогресс, 1986. 396 с.

13. Гонсалес Х.Л. История христианства: в 2 т. Т. 1. От основания Церкви до эпохи Реформации / пер. с англ. Б.А. Скороходова. СПб: Издание религиозной организации «Христианское общество «Библия для всех»», 2005.400 с.

14. Дворецкий И.Х. Латинско-русский словарь. М.: Русский язык, 1976. 1096 с.

94 Ле Гофф Ж. Цивилизация Средневекового Запада. С. 234.

95 Бурдах К. Реформация. Ренессанс. Гуманизм. С. 49.

96 Клестов А.А. Предисловие. С. v, vi. 


\section{Психология и психотехника 8(59) • 2013}

15. Делюмо Ж. Цивилизация Возрождения / Пер. с франц. И. Эльфонда. Екатеринбург: У-Фактория, 2006. 720 с.

16. Задворный В.Л. Святой Бонавентура и его эпоха // Бонавентура. Путеводитель души к Богу. М.: Греко-латинский кабинет Ю.А. Шичалина, 1993. С. 4-39.

17. История Средних веков: в 2 т. Т. 1 / под ред. С.П. Карпова. М.: Изд-во Московского университета: Наука, 2005. $681 \mathrm{c}$.

18. История Средних веков: в 2 т. Т. 2: Раннее новое время / под ред. С.П. Карпова. М.: Изд-во Московского университета; Наука, 2005. 432 с.

19. Карпов А.О. Эпистемическая вещь и ее артефакты // Психология и психотехника. 2012. № 8 (47). С. 7-28.

20. Карсавин Л.П. Культура Средних веков. М.: Книжная находка, 2003. 222 с.

21. Кереньи К. Дионис: Прообраз неиссякаемой жизни. М.: Ладомир, 2007. 319 с.

22. Клестов А.А. Предисловие // Цветочки славного мессера святого Франциска и его братьев. СПб: Журнал «Нева»; Издательско-торговый дом «Летний сад», 2000. С. v-xxxvi.

23. Косиков Г.К. Средние века и Ренессанс. Теоретические проблемы // Методологические проблемы филологических наук. Сборник научных трудов. М.: Изд-во Московского университета, 1987. С. 222-252.

24. Кун Т.С. Структура научных революций / пер. с англ. И.З. Налетова. М.: Прогресс, 1977. 300 с.

25. Ле Гофф Ж. Другое Средневековье: время, труд и культура Запада / пер. с франц. С.В. Чистякова и Н.В. Шевченко. Екатеринбург: Изд-во Уральского университета, 2002. 328 с.

26. Ле Гофф Ж. Цивилизация средневекового Запада / пер. с франц. под общ. ред. В.А. Бабинцева. Екатеринбург: У-Фактория, 2005. 560 с.

27. Мак-Ким Дональд К. Вестминстерский словарь теологических терминов. М.: Республика, 2004. 503 с.

28. Макьявелли Н. История Флоренции / пер. с итал. Н.Я. Рыковой. М.: Наука, 1987. 448 с.

29. Неретина С.С. Возможности понимания // Антология средневековой мысли (Теология и философия европейского Средневековья): в 2 т. Т. 1 / под ред. С.С. Неретиной. СПб: Изд-во Российского христианского гуманитарного института, 2001. 539 с.

30. Табачникова С.В. Комментарий // Фуко М. Воля к истине: по ту сторону знания, власти и сексуальности. Работы разных лет. М.: Касталь, 1996. С. 327-395.

31. Уивер Р.Х. Божественная благодать и человеческое действие: исследование полупелагианских споров / пер. с англ. А.В. Кырлежева. М.: Центр библейско-патрологических исследований; Империум Пресс, 2006. 336 с.

32. Флорский Иоахим. Согласование Ветхого и Нового Заветов / пер. с лат. М.Я. Якушкина // Антология средневековой мысли (Теология и философия европейского Средневековья): в 2 т. Т. 1 / под ред. С.С. Неретиной. СПб: Изд-во Российского христианского гуманитарного института, 2001. С. 509-537.

33. Фуко М. Воля к знанию. История сексуальности. Т. 1 // Фуко М.. Воля к истине: по ту сторону знания, власти и сексуальности. Работы разных лет / пер. с франц. С.В. Табачниковой. М.: Касталь, 1996. С. 97-268.

34. Хейзинга Й. Осень Средневековья. Исследование форм жизненного уклада и форм мышления в XIV и XV вв. во Франции и Нидерландах / пер. с франц. Д.В. Сильвестра. М.: Наука, 1988. 540 с.

35. Чекалов К.А. Буркхардт и наука о Возрождении // Буркхардт Я. Культура Италии в эпоху Возрождения. М.: Интрада, 1996. С. 5-12.

36. Foucault M. Dits et écrits. 1954-1988. En 4 volumes. T. III. P.: Callimard, 1994.

\section{References (transliteration):}

1. Bahmutskiy V.Ya. Na rubezhe dvuh vekov // Spor o drevnih i novyh. M.: Iskusstvo, 1985. S. 7-40.

2. Blazhennyy Avgustin. Ispoved' / Per. s lat. diak. A. Gumerova. M.: Izd-vo Sretenskogo monastyrya, 2007. 448 s.

3. Blazhennyy Avgustin. Ob upreke i blagodati // Blazhennyy Avgustin. Antipelagian-skie sochineniya pozdnego perioda / Per. s lat. D.V. Smirnova. M.: AS-TRAST, 2008. S. 217-272.

4. Blazhennyy Avgustin. Pis'mo 217-e. K Vitaliyu Karfagenskomu // Blazhennyy Avgu-stin. Antipelagianskie sochineniya pozdnego perioda / Per. s lat. D.V. Smirnova. M.: AS-TRAST, 2008.S. 273-298.

5. Blok M. Feodal'noe obschestvo // Blok M. Apologiya istorii, ili Remeslo istorika / Per. s franc. E.M. Lysenko. M.: Nauka, 1986. S. 122-181.

6. Bodriyyar Zh. Sistema veschey / Per. s franc. S.N. Zenkina. M.: Rudomino, 1995. 174 s.

7. Burdah K. Reformaciya. Renessans. Gumanizm / Per. s nem. M.I. Levinoy. M.: Rossiyskaya politicheskaya enciklopediya (ROSSPEN), 2004. $208 \mathrm{~s}$. 


\section{Философия и психология}

8. Burkhardt Ya. Kul'tura Italii v epohu Vozrozhdeniya / Per. s nem. A.E. Mahova. M.: Intrada, 1996. 528 s.

9. Vazari Dzh. Zhizneopisaniya naibolee znamenityh zhivopiscev, vayateley i zodchih. V 5-ti t. T. 1 / Per. A.I. Venediktova. M.: TERRA, 1996. $608 \mathrm{~s}$.

10. Veysman A.D. Grechesko-russkiy slovar'. Reprint V-go izdaniya 1899 g. M.: Greko-latinskiy kabinet Yu.A. Shichalina, 2006. $1371 \mathrm{~s}$.

11. Vorob'ev L. Utopii i deystvitel'nost' // Utopicheskiy roman XVI-XVII vekov. M.: Hudozhestvennaya literatura, 1971. S. 5-38.

12. Garen E. Problemy ital'yanskogo Vozrozhdeniya. Izbrannye raboty. M.: Progress, 1986. $396 \mathrm{~s}$.

13. Gonsales H.L. Istoriya hristianstva. V 2-h t. T. 1. Ot osnovaniya Cerkvi do epo-hi Reformacii / Per. s angl. B.A. Skorohodova. SPb: Izdanie religioznoy organiza-cii «Hristianskoe obschestvo «Bibliya dlya vseh», 2005. $400 \mathrm{~s}$.

14. Dvoreckiy I.H. Latinsko-russkiy slovar'. M.: Russkiy yazyk, 1976. $1096 \mathrm{s.}$

15. Delyumo Zh. Civilizaciya Vozrozhdeniya / Per. s franc. I. El'fonda. Ekaterinburg: U-Faktoriya, 2006. 720 s.

16. Zadvornyy V.L. Svyatoy Bonaventura i ego epoha // Bonaventura. Putevoditel' dushi k Bogu. M.: Greko-latinskiy kabinet Yu.A. Shichalina, 1993. S. 4-39.

17. Istoriya Srednih vekov. V 2-h tomah. Tom 1 / Pod red. S.P. Karpova. M.: Izd-vo Moskovskogo universiteta: Nauka, 2005. $681 \mathrm{~s}$.

18. Istoriya Srednih vekov. V 2-h tomah. Tom 2: Rannee novoe vremya / Pod red. S.P. Karpova. M.: Izd-vo Moskovskogo universiteta; Nauka, 2005. $432 \mathrm{~s}$.

19. Karpov A.O. Epistemicheskaya vesch’ i ee artefakty // Psihologiya i psihotehnika. 2012. № 8 (47). S. 7-28.

20. Karsavin L.P. Kul'tura Srednih vekov. M.: Knizhnaya nahodka, 2003. 222 s.

21. Keren'i K. Dionis: Proobraz neissyakaemoy zhizni. M.: Ladomir, 2007. 319 s.

22. Klestov A.A. Predislovie // Cvetochki slavnogo messera svyatogo Franciska i ego brat’ev. SPb: Zhurnal «Neva»; Letniy sad, 2000. S. v-xxxvi.

23. Kosikov G.K. Srednie veka i Renessans. Teoreticheskie problemy // Metodologicheskie problemy filologicheskih nauk. Sbornik nauchnyh trudov. M.: Izd-vo Moskov-skogo universiteta, 1987. S. 222-252.

24. Kun T.S. Struktura nauchnyh revolyuciy / Per. s angl. I.Z. Naletova. M.: Progress, 1977. 300 s.

25. Le Goff Zh. Drugoe Srednevekov'e: vremya, trud i kul'tura Zapada / Per. s franc. S.V. Chistyakova i N.V. Shevchenko. Ekaterinburg: Izd-vo Ural'skogo universiteta, 2002. 328 s.

26. Le Goff Zh. Civilizaciya srednevekovogo Zapada / Per. s franc. pod obsch. red. V.A. Babinceva. Ekaterinburg: UFaktoriya, 2005. $560 \mathrm{~s}$.

27. Mak-Kim Donal'd K. Vestminsterskiy slovar' teologicheskih terminov. M.: Respublika, 2004. 503 s.

28. Mak'yavelli N. Istoriya Florencii / Per. s ital. N.Ya. Rykovoy. M.: Nauka, 1987. 448 s.

29. Neretina S.S. Vozmozhnosti ponimaniya // Antologiya srednevekovoy mysli (Teologiya i filosofiya evropeyskogo Srednevekov'ya). V 2-h t. T. 1 / Pod red. S.S. Neretinoy. SPb.: Izd-vo Rossiyskogo hristianskogo gumanitarnogo instituta, 2001. $539 \mathrm{~s}$.

30. Tabachnikova S.V. Kommentariy // Fuko M. Volya k istine: po tu storonu znaniya, vla-sti i seksual'nosti. Raboty raznyh let. M.: Kastal', 1996. S. 327-395.

31. Uiver R.H. Bozhestvennaya blagodat' i chelovecheskoe deystvie: issledovanie polupela-gianskih sporov / Per. s angl. A.V. Kyrlezheva. M.: Centr bibleysko-patrologicheskih issledovaniy; Imperium Press, 2006. 336 s.

32. Florskiy Ioahim. Soglasovanie Vethogo i Novogo Zavetov / Per. s lat. M.Ya. Yakushkina // Antologiya srednevekovoy mysli (Teologiya i filosofiya evropeyskogo Sredneve-kov'ya). V 2-h t. T. 1 / Pod red. S.S. Neretinoy. SPb.: Izd-vo Rossiyskogo hristianskogo gumanitarnogo instituta, 2001. S. 509-537.

33. Fuko M. Volya k znaniyu. Istoriya seksual'nosti. T. 1 // Fuko M. Volya k isti-ne: po tu storonu znaniya, vlasti i seksual'nosti. Raboty raznyh let / Per. s franc. S.V. Tabachnikovoy. M.: Kastal', 1996. S. 97-268.

34. Heyzinga Y. Osen' Srednevekov'ya. Issledovanie form zhiznennogo uklada i form myshleniya v XIV i XV vekah vo Francii i Niderlandah / Per. s franc. D.V. Sil'vestra. M.: Nauka, 1988. 540 s.

35. Chekalov K.A. Burkhardt i nauka o Vozrozhdenii // Burkhardt Ya. Kul'tura Italii v epohu Vozrozhdeniya. M.: Intrada, 1996. S. 5-12.

36. Foucault M. Dits et écrits. 1954-1988. En 4 volumes. T. III. P.: Callimard, 1994. 